\title{
Identification of Potential Participant Scientists and Development of Procedures for a National Inventory of Selected Biological Monitoring Programs: A Mail Questionnaire Survey
}

\author{
H. T. Kemp \\ F. G. Goff \\ J. W. Ross \\ MASTER \\ ENVIRONMENTAL SCIENCES DIVISION \\ Publication No. 1133
}

OAK RIDGE NATIONAL LABORATORY OPERATED BY UNION CARBIDE CORPORATION - FOR THE DEPARTMENT OF ENERGY 


\section{DISCLAIMER}

This report was prepared as an account of work sponsored by an agency of the United States Government. Neither the United States Government nor any agency Thereof, nor any of their employees, makes any warranty, express or implied, or assumes any legal liability or responsibility for the accuracy, completeness, or usefulness of any information, apparatus, product, or process disclosed, or represents that its use would not infringe privately owned rights. Reference herein to any specific commercial product, process, or service by trade name, trademark, manufacturer, or otherwise does not necessarily constitute or imply its endorsement, recommendation, or favoring by the United States Government or any agency thereof. The views and opinions of authors expressed herein do not necessarily state or reflect those of the United States Government or any agency thereof. 


\section{DISCLAIMER}

Portions of this document may be illegible in electronic image products. Images are produced from the best available original document. 


\section{Printed in the United States of America. Available from National Technical Information Service \\ U.S. Department of Commerce \\ 5285 Port Royal Road, Springfield, Virginia 22161 \\ Price: Printed Copy $\$ 4.50$; Microfiche $\$ 3.00$}

This report was prepared as an account of work sponsored by an agency of the United States Government. Neither the United States Government nor any agency thereof, nor any of their employees, contractors, subcontractors, or their employees, makes any warranty, express or implied, nor assumes any legal liability or responsibility for any third party's uso or tho rosulte of euch uвe of any information, apparatus, product or process disclosed in this report, nor represents that its use by such third party would not infringe privately owned rights. 
Contract No. W-7405-eng-26

IDENTIFICATION OF POTENTIAL PARTICIPANT SCIENTISTS AND DEVELOPMENT OF PROCEDURES FOR A NATIONAL INVENTORY OF SELECTED BIOLOGICAL MONITORING PROGRAMS: A MAIL QUESTIONNAIRE SURVEY

\author{
H. T. Kemp, F. G. Goff, and J. W. Ross*
}

ENVIRONMENTAL SCIENCES DIVISION

Publication No. 1133

*Present Address: Education Department, Call away Gardens, Pine Mountain, Georgia 81822

Date Published - March 1978

\author{
OAK RIDGE NATIONAL LABORATORY \\ Oak Ridge, Tennessee 37830 \\ operated by \\ UNION CARBIDE CORPORATION \\ for the \\ DEPARTMENT OF ENERGY
}




\section{THIS PAGE}

\section{WAS INTENTIONALLY \\ LEFT BLANK}




\section{ACKNOWLEDGMENTS}

We were assisted in developing the mailing list and documentation form design by John S. Cherry, Gregory J. Kauffman, and Gayle E. Whittaker of the Biomonitoring Staff, and we gratefully acknowledge the questions raised and ideas shared by these individuals. We also wish to acknowledge the contribution of Dr. Robert L. Burgess, Mr. Richard J. Olson, and other members of the Environmental Sciences Division staff for reviewing the questionnaire and making useful suggestions regarding its design. Staff members of the sponsoring organizations and ecologists identified by the Institute of Ecology reviewed, pretested, and approved the questionnaire.

Funding for this project was supplied by the Council on Environmental Quality, the Fish and Wildlife Service, the Energy Research and Development Administration -- now Department of Energy, and the National Marine Fisheries Service. 
THIS PAGE

WAS INTENTIONALLY

LEFT BLANK 


\section{ABSTRACT}

H. T. Kemp, F. G. Goff, and J. W. Ross. 1978. Identification of potential participant scientists and development of procedures for a national inventory of selected biological monitoring programs: a mail questionnaire survey. ORNL/TM-6224. Oak Ridge National Laboratory, Oak Ridge, Tennessee. 46 pp.

Procedural details of how the National Biological Monitoring Inventory was conducted are described. Results of a nation-wide telephone campaign to identify principal investigators and also of a nation-wide questionnaire mailing to the investigators identified are presented. On the basis of percentage of questionnaire returns (nearly $50 \%$ ), the Inventory was judged to be successful. The communication procedures, guidelines, and formats developed may be useful to others engaged in this type of research. 


\section{THIS PAGE}

\section{WAS INTENTIONALLY LEFT BLANK}




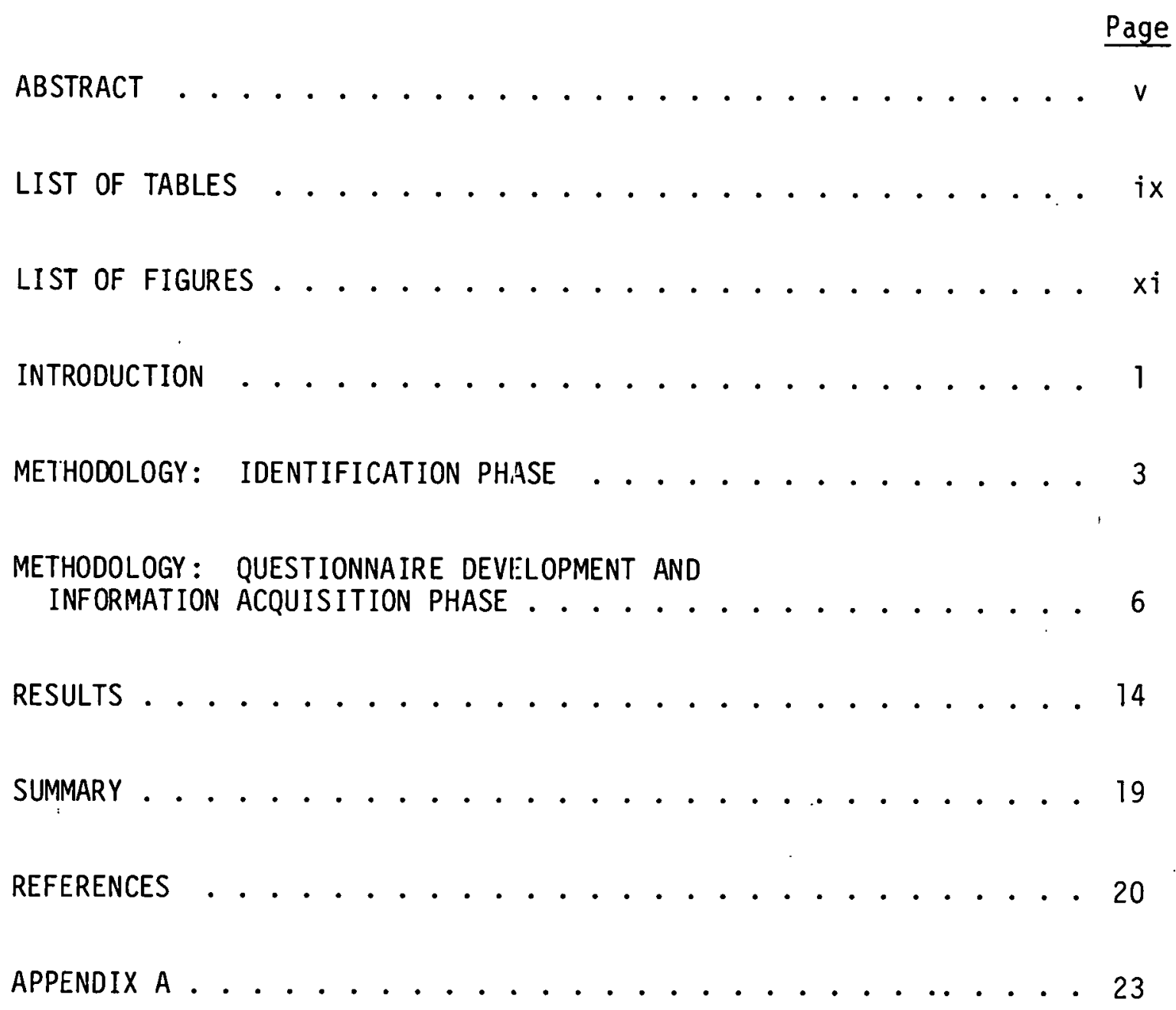




\section{THIS PAGE}

\section{WAS INTENTIONALLY LEFT BLANK}




\section{LIST OF TABLES}

Table

1 Biological monitoring definition sheet used by individuals conducting telephone interviews . . . . . . . . . . . 7

2 Biological monitoring checklist of items covered in telephone interviews . . . . . . . . . . . . . . . 8

3 Sumary of guidelines for improving returns in mailed questionnaire surveys................. . 9

4 Estimated numbers of principal investigators by source of identification ................... 16

5 Summary of mailing to, responses from, and referrals by principal investigators contacted in the National Biomonitoring Inventory ................ . 17 


\section{THIS PAGE}

\section{WAS INTENTIONALLY \\ LEFT BLANK}




\section{LIST OF FIGURES}

Figure

Page

1 Identification of potential participants for a mailed questionnaire survey ........... . 5 
INTRODUCTION

During the sumer of 1975 a national inventory of biological monitoring activities was initiated at Oak Ridge National Laboratory (ORNL) for the Council on Environmental Quality (CEQ) in cooperation with the Department of Energy (then Energy Research and Development Administration, ERDA), the Fish and Wildlife Service, and the National Marine Fisheries Service. CEQ had difficulty in identifying and acquiring the growing body of information on trends of change in the biota and environments of the country. It was their hope that ORNL, with its strengths in both biological/environmental data analys is and information science, could develop a national data base on biological monitoring projects that would permit more effective evaluation of such trends. The effort was also stimulated by the recognition that a very large investment is currently involved in the collection of biological monitoring information. The biomonitoring project is a nationwide overview inventory of biological monitoring programs.

The purpose of this report is to describe how the work was initiated, and, in particular, (a) how a systematic interview technique was used to develop the directory of projects and persons to whom copies of the documentation form (questionnaire) were mailed, (b) how the questionaire on biomonitoring projects was designed and the mailing and information acquisition sequence was actually conducted.

Unlike information on the physical quality of air and water, biomonitoring data and their sources are extremely diverse and a coherent capability to overview the ir scope is lacking. There has been little success in comprehensively compiling or analyzing our Nation's biological data bases and programs in ways that might be helpful in assessing biotic conditions and trends. Apparent ly, the ineffectiveness of such efforts has resulted partly from the considerable difficulty and expense of most types of biological monitoring, as well as from the great diversity in objectives, types, sources, quality, and availability of the biological data. The lack of a comprehensive analysis of our biological monitoring programs and data bases has also resulted from agency parochialism. Jenkins (1974) states:

\footnotetext{
"Ecological research activities are scattered throughout many agencies of the federal government with little overall coordination, direction, or definition of priorities. Large volumes of survey, monitoring, and research information of ecological value are gathered by Federal agencies, but with limited or specialized use, generally primarily by the collecting agency. These data, together with non-federal information, constitute resources of enormous value if selected, focused, analyzed, and integrated for applicability to specific
} 
environmental problems to strengthening the ecological basis for regulatory actions in land, water, air and resource management, and to mitigation of environmental impacts. Without a federal focus, response to problems which require ecological information or capability will continue to be fragmented, costly, redundant and reflexive rather than strategic, efficient and contributory to national goals and productivity."

With mounting concern for environmental quality, rapid identification of and access to available biological resource data become increasingly important. Such data are required for environmental analyses and evaluation programs, for decision-making at all levels of private enterprise and government, for regional and global assessments of environmental impacts, and for regulatory purposes.

In approaching the masstve antourt of available biological infor... mation, we asked ourselves first whether or not biomonitoring information could be put into consistent form. There was alsu d reed, however, to strike a healthy balance between standardization and flexibility. Standardization permits rapid identification of relevant information and provides for quick access and acquisition of such information. Flexibility assures that data formats reflect the nature of highly varied information on different systems and components, and also results in minimal interference with the heuristic element so vital to free inquiry in science. The first task of an inventory is to collect, assemble, and make available information about the biomonitoring projects currently in progress in the nation. From this inventory of widely dispersed information, selected samples can be drawn and efforts toward analysis and evaluation can be made.

An important characteristic of the collection of data for the Nationa 1 Biomonitoring Inventory at ORNL is that information is requested only for current or recently completed projects (1.e. those completed within the past 3-5 years). This has the effect of shortening documentation time. The usual journal publication/abstract service summarization route may require more than a year for completion after documents are published. Report writing delays can, in some instances, extend this several additional years. The procedure described in this report can shorten documentation time to as little as six months. A further advantage is that important unpublished information, e.g., environmental impact reports and management documents on wildlife in state files, is included in the mix of information received. In the rapidly developing biomonitoring field, Faster identification and broader coverage of unpublished information can be important to administrators in shaping policy and programming planning decisions. The biomonitoring project is designed to address these needs.

Our approach to collecting these data was to first identify monitoring activities from various sources, then to contact administrative 
level personnel to obtain lists of monitoring projects (with names and addresses of persons responsible), and finally to mail questionnaires to principal investigators for accumulating detailed information on each project. The results were entered into computer-accessible files to facilitate storage, retrieval, updating, and analysis. Reports describing the National Biological Monitoring Program in more detail have been written (Kemp and Burgess 1976, Kemp 1977, Suffern et al. $1976)$.

\section{METHODOLOGY: IDENTIFICATION PHASE}

Identification of a select set of potential participants for a mail questionnaire survey, i.e., inventory, is an important aspect of this type of information-gathering endeavor if a high degree of participation is desired. Many mail surveys are conducted in a random manner and a high level of response is not expected. Often, the hope is that enough response will be received to allow a statistically valid sampling of information or to estimate the size of the potential participant population. When the questionnaire solicits succinct summaries of technological or scientific studies and is to be input into a computerized data base, comprehensive coverage of potential participants becomes a very important consideration. Mailing to nonapplicable persons results in unnecessary expenditure of time and funds. Potential participants are more likely to respond if they are correctly identified and carefully screened beforehand to assure project relevance.

The objectives of the potential participant identification phase of the National Biomonitoring Inventory were to:

1. Identify and obtain addresses of principal investigators involved in biological monitoring studies throughout the U. S.

2. Refine the definition of biomonitoring and assess the comprehensiveness of coverage of national biomonitoring projects by the Inventory.

3. Develop a plan for an initial and continued high degree of coverage of biomonitoring projects.

We achieved a high degree of potential participant coverage mainly through the use of a systematic telephone interview technique to develop a directory of projects and individuals. This directory was then used for preparing address labels for mailing the questionnaire.

A telephone campaign was originally planned to achieve the first objective, but this approach was subsequently revised. The plan was to place telephone calls to each of an estimated 1100 principal 
investigators involved in biological monitoring. This involved identifying these persons from various directories (see References), describing the objectives of the Inventory to them, soliciting the ir agreement to participate, acquiring limited information about the ir biomonitoring program, and asking for referrals to other similar efforts.

As a result of trial telephone calls to several states, the original estimate of 1100 potential contacts in the U. S. was raised. As the estimate of the number of projects increased, we became aware that it would not be possible (within time and budget constraints) to contact all biomonitoring project principal investigators by phone. Consequent ly, several changes were made that we believe resulted in better coverage: (1) emphasis was placed on calling program-level or key administrators. Primary emphasis was placed on identifying key administrators in appropriate departments of state and local governments, universities and colleges, research laboratories, consulting firms, and business organizations. These individuals were asked to identify and provide addresses of principal investigators at the project level; (2) efforts to acquire specific information on each biomonitoring project were dropped, with sole reliance on the mailed questionnaire for subsequent information development; and (3) increased emphasis was placed on obtaining referrals, i.e., other administrators or investigators, from the key administrators called. The list of names and addresses was compiled primarily from such phone calls, although a simultaneous, parallel effort was also made to interview selected officials in pertinent federal agencies (e.g. Forest Service -USDA, Fish and Wildlife Service -- Department of Interior). In addition to nominations resulting from telephone interviews, referrals from filled-in questionnaires were incorporated as they were received. These indirect referrals were included in a later questionnaire mailing.

In addition to gathering technical information about the project or projects within a particular program, the callers attempted to establish effective liaison with the project contact person in whatever way possible. Thus, callers attempted to listen carefully and reflectively to the project description, to make constructive comments wherever possible, to empathize with the contact person and understand project.goals, and to maintain and convey an attitude of genuine interest. This was done even for those projects that did not qualify directly under our definition of biological monitoring. The objective of the telephone interview was not only to gain information for the directory but also to gain effective support of the person on the other end of the line.

The procedure used in securing the initial telephone identifications (nominations) and compiling the addresses of principal investigators is schematically diagramed in Fig. 1 . Most of the potential contributors were directly identified by the telephone interview sequence $(A, B, C, F)$. Fewer were identified by the telephone referral route $(A, B, C, E, F)$, and fewer still were identified by the 


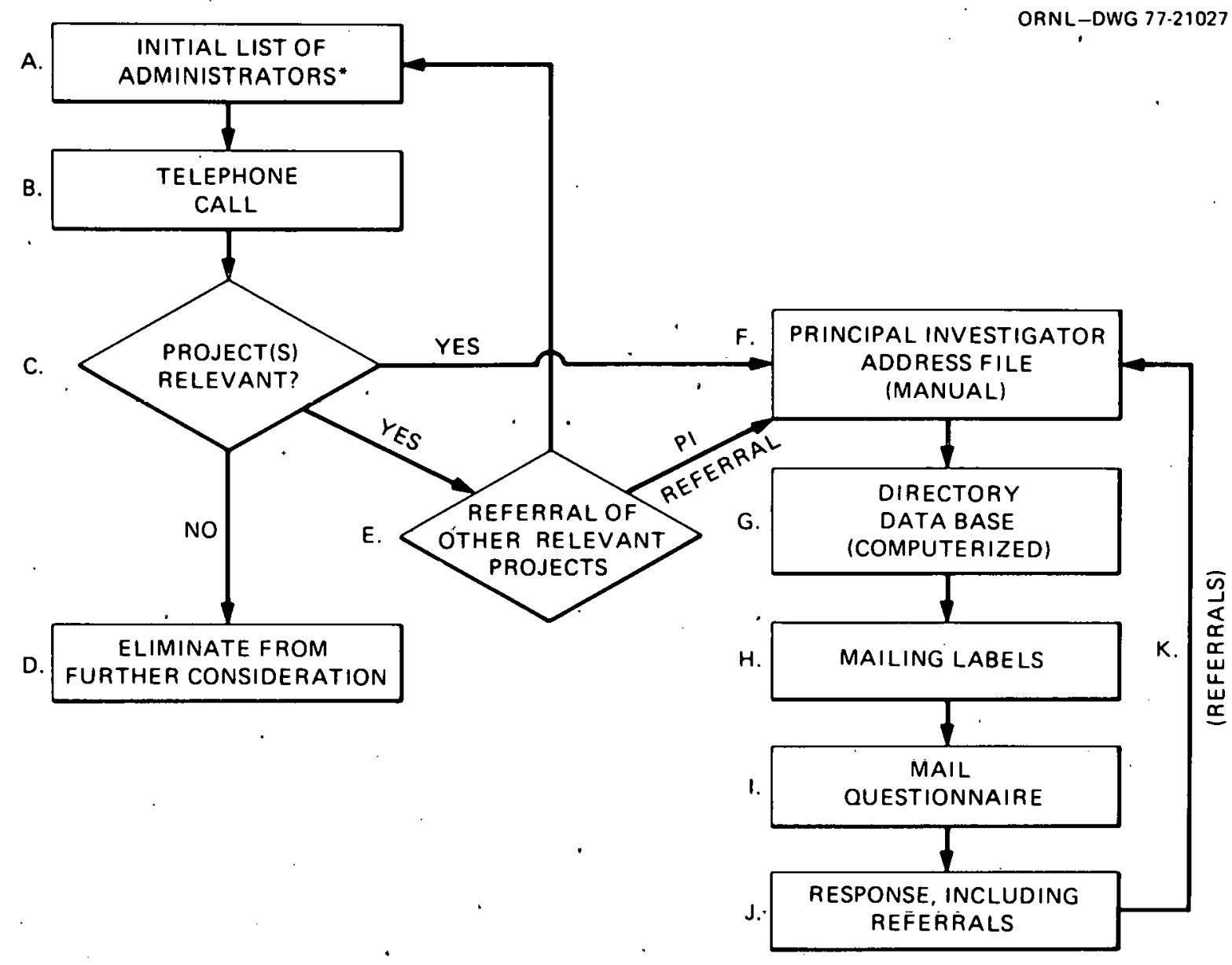

-FROM VARIOUS ENVIRONMENTAL DIRECTORIES, REFERRALS, AND PERSONAL INTERVIEWS (SEE TEXT).

Fig. 1. Identification of potential participants for a mailed questionnaire survey. 
questionnaire referral route $(A, B, C, F-K)$. The number of referrals from questionnaires resulting in new addresses (K) served as an indication of comprehensiveness of coverage. As previously noted, a significant number of investigators were identified by interview of federal officials (not shown in Fig. 1).

To assure adequate conversational communication, each caller was supplied with a sheet defining the biomonitoring effort (Table 1) and a checklist of items to be covered (Table 2). Neither was intended as a rigid format for conversation, but rather as a guideline to ensure that most important informational elements were imparted to the person called.

\section{METHODOLOGY: QUESTIONNAIRE DEVELOPMENT AND INFORMATION ACQUISITION PHASE}

Our purpose was to design a questionnaire that would give a maximum amount of information about biomonitoring projects throughout this country, and yet to make the questionnaire brief enough and easy enough to fill out that we would achieve a high rate of return. The content of the questionnaire was determined by (a) reference to questionnaires used in several other biological and technological inventories, (b) interviews with colleagues in the fields of information and environmental science, (c) review with the biomonitoring project staff, and (d) pretesting within the Environmental Sciences Division at Oak Ridge National Laboratory and nationwide with a group of the Institute of Ecology (TIE) members.

The mailed questionnaire approach to developing information depends on a high degree of participation by those queried. In an attempt to enhance participation, a review of pertinent literature on questionnaire design was conducted. The purpose of this review was to identify features of questionaire design which would contribute to a high rate of return. Most, but not all, of the suggestions made in these literature sources were incorporated into our design. The information obtained from the review is briefly sumarized in Table 3 in the form of a list of questionnaire features suggested by various sources. 
Table 1. Biological monitoring definition sheet used by individuals conducting telephone interviews

"A NATIONAL INVENTORY OF B IOLOGICAL MONITORING PROGRAMS"

DEFINITIONS

- BIOMONITORING - BIOLOGICAL MONITORING - MONITORING NATURAL BIOTA

- CHANGES - CHANGES WITH TIME - ANALYSIS OF CHANGES WITH TIME

- NATURAL BIOTA - ALL NATURALLY OCCURRING PLANT AND ANIMAL SPECIES EXCLUDING HUMANS AND DOMESTIC ANIMALS AND CROP PLANTS

- PROJECT -- LOWEST LEVEL ORGANIZATIONAL FIELD UNIT, I.E., JOB, TASK, OR SUB-PROJECT IN SOME ESTABLISHMENTS

- PROGRAM -- ORGANIZATIONAL GROUPING OF PROJECTS FOR ADMINISTRATIVE OR COORDINATING PURPOSES AT NATIONAL, INTERSTATE, REGIONAL, OR LOCAL LEVELS

For this inventory, biological monitoring is defined as any data collecting project in which living organisms are systematically and continuously or periodically identified with generation of appropriate data. Field biology and aquatic studies that develop data on numbers, species, geographical location of sampling, and apparent population trends are good examples. Particular interest is focused on those current monitoring efforts that have resulted in establishment of a we 1l-defined population change with time. Interest extends also to new programs that may establish such trends in the future, and past programs that have established important trends.

Excluded from the definition are water quality monitoring, hydrological, and meteorological programs in which only physical-chemical data are taken. However, water or weather data taken in conjunction with a biological monitoring project are of interest. ERTS-type remote sensing is also not part of the present consideration.

Further exclusions from the biomonitoring definition are agriculture and silviculture (monocultured crops) except as they may impact on natural populations; studies of domestic animals and humans; e.g. health physics and occupational or comiunicable diseases; and any related pathogens or parasites. Similarly, economic and production statistics are excluded.

Studies in continental shelf waters fit the biological monitoring definition, but deep-sea studies past these waters do not.

Biological monitoring projects include those in which the following pardmeters are studies:

1. Organisms - a single species; species in similar, specific taxonomic groupings; or types of organisms are identified and enumerated or measured in some manner.

2. Location - geographically defined single sampling location (site), series of coordinated sampling sites or stations, or region.

3. Time - periodic sampling are taken with some degree of regularity.

In all cases, information on these aspects of your project constitute the minimal documentation required. For further clarification of the definition of biological monitoring, brief review of the project. documentation form is suggested. 
Table 2. Biological monitoring checklist of items covered in telephone interviews

PRESIDENT'S COUNCIL ON ENVIRONMENTAL QUALITY

Environmental Sciences Division, ORNL P.0. Box $X$

Oak Ridge, Tennessee 37830

\section{TELEPHONE CHECKLIST}

FOUR (4) CRITERIA:

--monitoring must be hinlngical--measuring natural biota;

--monitoring must be presently ongoing or to be continued;

--monitoring must be applicably to analysis and evaluation of changes through time; and

--monitoring should, preferably, be concerned with measuring some environmental stress or disturbance and is of special interest if it pertains to endangered plant or animal species or threatened natural microhabitats and land features (e.g., salt marshes, mangrove swamps, and wild or scenic rivers.).

SIX (6) RESTRICTIONS:

--crop production economics, agriculture, and silviculture-type surveys excluded;

--household and agricultural pest-control oriented surveys excluded;

$=-$ health or other monitoring of humans as a species and of domestic and farm animals excluded;

--one-shot counts or surveys (see change through time analys is above) excluded;

--monitoring solely of physical-chemical parameters e.g., water quality and meteorological studies; and

--remote sensing by satellite, e.g. ERTS.

Within the abuve-uullined scope, spccific information we nepd from this irlitial telephone rontact includes:

--principal investigator demographics (name, address, phone number);

--suggested referrals;

--total number of Principal Investigators with this organization. 
Table 3. Summary of guidelines for improving returns in mailed questionnaire surveys.

Summarized guidelines

References

Questionnaire format

1. Printed forms are preferred over typed and typed over mimeographed

Miller 1970,

Young et al. 1970

2. Artwork is considered a positive factor on the questionnaire

Young et al. 1970

3. Do not ask important or taxing questions last

Young et a1. 1970

4. If the questionnaire is long, print on both sides, and attempt to convey the impression that the questionnaire is short

Champion 1969, Miller 1970, Young et al. 1970

5. Avoid a crowded appearance and maximize white space

Babbie 1973, Miller 1970, Young et al. 1970

6. Simplify the response categories--use checklists where possible.

Young et al. 1970

7. Varying the type for emphasis is desired

8. Apparent length is more important than actual length

Young et al. 1970

Babbie 1973, Champion and Sear 1969

9. Longer questionnaires are returned most frequently, all else being held constant

Champion and Sear 1969

10. Type face must be easily readable Miller 1970

11. The respondent who finds he has spent considerable time on the first page of what seemed a short questionnaire will be more demoralized than the respondent who quickly completed the first several pages of what initially seemed rather long

Babbie 1973 
Table 3. (continued)

Questionnaire format (continued)

12. Boxes for response are better than brackets, brackets better than parentheses, parentheses

Babbie 1973

better than a rhombus, and a rhombus better than

a line for checkoff; but circling coded

responses is acceptable with instructions to

avoid crossing out or checking off code

numbers as a response

13. Colored paper is preferred over white

Matteson et al. 1974

\section{Pretesting}

14. Pretesting is "essential"

Young et a1. 1970

15. Pretesting should be made on a small random sample

Young et al. 1970

\section{Covering letter}

16. Covering letter should be as personalized as possible thus avoiding the appearance of a form letter

Champion and

Sear 1969,

Dillman and

Frey 1974,

Etzel et a1. 1974, Mattcson 1974,

Rob in 1974,

Young et al. 1970

17. Covering letter should be signed in a color other than that of the printing or typing on the letter

Dillman and

Frey 1974,

Etzel et al. 1974,

Young et al. 1970

18. In closing the letter, use an official title below the signature

Miller 1970

19. Letter should be on official stationary

Young et al. 1970 
Table 3. (continued)

Covering letter (continued)

20. The letterhead should convey the impression of scientific competence

Miller 1970, Young et al. 1970

21. Any previous contacts should be reiterated

Robin 1974

22. Emphasize the inclusion of a stamped return envelope in each letter of correspondence

Robin 1974

23. The covering letter should not bear the sole burden of instructing how the questionnaire is to be filled out and returned--duplicate any such information on the questionnaire itself

24. Leave a space for typing in the addressee's. name after the opening salutation for added personalization

25. The altruistic approach is favored over personal gain or the egoistic-oriented letter where professionals are concerned

Robin 1974

26. The signalure of the researcher alone, with Kawash and or without ident ifying $h$ is rank, has no signiflcant effect on the return rate from fellow faculty members

Robin 1974

Champion and Sear 1969, Miller 1970 Aleamoni 1971

\section{Return Envelopes}

27. Stamped postal permit (not metered), self addressed envelopes are effective

Babbie 1973, Eck land 1965, Champion and Sear 1969, Etzel et al. 1974, Hochst im 1970, Mattesori 1974, Miller 1970, Robin 1974, Young et al. 1970 
Table 3. (continued)

Return Envelopes (continued)

28. Self-mailing questionnaire can be incorporated

Babbie 1973 as part of the questionnaire design so no envelope is necessary; use a business reply permit for return mail

Mailing

29. First class is favored over third class

Young et al. 19\%

30. Actual stamp is favored over postal permit and postal permit over metered stamp

Champion and Sear 1969, Robin 1974

31. Timing is important, for example, not at the end of a budget year

32. Special delivery postage cost in follow-up mailings is justified

Miller 1970,

Robin 1974

Champion and

Sear 1969

33. Use a certified letter on follow-up mailings

Eck l and 1965

Follow-up letters

34. Limit to three follow-up letters

Babbie 1973,

Eck land 1965, Robin 1974, Young et al. 1974

35. Post card mailed three days after questionnaire mailing urging response is effective

Nichols and Meyer 1974, Young et al. 1970

36. At least a short period should elapse before the first follow=up letter

Three days to one week (Robin 1974, Young et al. 1970); best response rate results from a combination of early and late 
Table 3. (continued)

follow-up letters, 3 and 16-27 days in combination (Nichols and Meyer 1974); five days (Etzel et al. 1974)

Follow-up letters

37. Use special delivery postage

Champion and Sear 1969

38. Telephone follow-up after three mail follow-

Eck land 1965 ups improves response rate

Other

39. Precoding questionnaire response categories for ease of data processing is convenient

Young et al. 1970

40. Prequestionnaire letter announcing and explaining survey is effective

Robin 1974

41. Protect the respondent's ego by not asking questions too difficult to answer

42. Avoid negative items, that is, those with a "not" in them which can be easily overlooked and give misleading answers

43. Pre-telephoning produces only earlier returns, not higher response rates

Milier 1970

Babbie 1973

Dillman and Frey 1974 
Procedures adopted or specifically taken into consideration are numbered $1-15,17,18,20-23,25-27,31,34,36,41$, and 42 . The questionnaire developed and used is shown in Appendix $A$ (pages $A-1$ through A-4). The covering letter is also included in Appendix $A$ (page A-5). In regard to follow-up (reminder) letters as noted in item 38, on ly two were forwarded. These follow-up letters are shown on pages $A-6$ and A-7 of Appendix A (Tables A-2 and A-3).

When filled-in questionnaire responses were received, each was assigned a unique accession number consisting of a two-letter state abbreviation [special acromyms were adopted for Canada (CN), Mexico $(M X)$, and Puerto Rico (PR)], denoting the source of response, and a consecutively assigned number. Thus, a running total of responses from each state was readily available: Other information, such as date received, degree of questionnaire completeness, and pertinence or lack of project applicability, was recorded. Information of this type was useful in determining the degree of success of telephoning and also of the mailing effort.

Most of the responses were received within two months of mailing, but occasional responses were received later.

\section{RESULTS}

Initially, telephone calls were made to key administrators in Florida and Tennessee to test the approach, to determine what problems might arise, and to better estimate the number of calls needed for national coverage. The initial number of key administrators identified for Florida was 37, while 25 were 1 isted for Tennessee. As a result of referrals from telephoning these persons, the number of administrators increased to 40 for Florida and 37 for Tennessee.

The number of principal investigators identified and nominated as a result of calls to administrators was 150 in Florida and 51 in Tennessee. Since only a limited set of referrals was obtained from each key administrator, and since these generally were directed to clnsely allied projects, we were concerned about the degree of coverage of projects within each state as a unit. Review of the initial list of investigators by knowledgeable persons in both states indicated that coverage of these states was not complete.

From the ir suggestions of additional projects for these two states, we estimated 150 investigators per state as a national average. While this estimate was little more than a educated guess, it proved useful in guiding the design of the inventory effort, and, in retrospect, has proven to be a reasonable compromise betweeri the number of principal investigators identified and the final total estimate (see below). 
Since the way in which biomonitoring is defined, project size, differentiation between inclusive projects or programs on the one hand and specific projects within a program on the other, and other factors affect the number of projects, at this early stage we could do little more than estimate the number of projects that we would be dealing with.

On the basis of this estimate, the U. S. population of principal investigators involved in biological monitoring appeared to be approximately $7500(150 \times 50)$. Subsequent calls to other states tended to confirm the 7500 estimate. Since staff members were also involved in design of the program, development of information checklists, definitions, and various other duties, an average of only about 8 calls per day per staff member could be completed. Time zone changes, equipment failures, inability to reach investigators, and many other, of ten frustrating delays held the number of successful calls below what we had originally thought possible. It became apparent that with only four staff members calling 7500 investigators was a physical impossibility in the three months scheduled for this effort. The original goal of calling all investigators in the $U$. S. was dropped in favor of attempting to locate and call most key administrators in the U. S., and asking for names and addresses of principal investigators for the questionnaire mailing list.

An estimation of numbers of principal investigators by identification source is shown in Table 4 . As previously noted, most were identified by telephone nomination by key administrators, while relatively few were identified by questionnaire referral and by personal interview of federal officials.

A sumary of identification sources of principal investigators is presented in Table 5. The numbers given are not absolute for several reasons, e.g., some administrators served in dual capacities as managers and also as principal investigators, and the procedures followed did not permit differentiation of this level of detail.

A total of 6268 questionnaire packages were sent in the initial mailing. The number of incorrect addresses was quite low (1.9\%), leaving 6133 delivered questionnaire packages. Responses were tallied whether positive (filled-in questionnaire) or negative (indication of no project or project nonapplicability). Accounting in this manner resulted in 2933 responses -- a response rate of $47.8 \%$ without inclusion of questionnaire referrals or volunteer responders.

Referrals from questionnaires totaled 606 with approximately $33 \%$ (199) being new names and approximately 67\% (407) being names of principal investigators previously identified (Table 4). This ratio $(1: 2=0.5)$ of new names to names already on our list provides an indication of the degree of coverage or "closure" obtained by the 
Table 4. Estimated numbers of principal investigators by source of identification

$\begin{array}{lll}\text { Est imated number } & \\ \text { of invesligators } & \text { Percent } \\ \text { identified } & \text { of total }\end{array}$

Nomination by key administrators ${ }^{a}$

4250

68

Telephone referrals by key administrators

1150

18

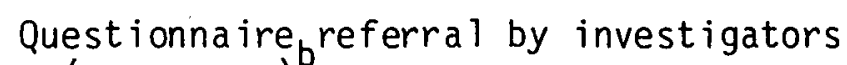
(new names)

Interview of federal officials

200

3

Total

700

11

6300

100

${ }^{a}$ Identified from environmental directories. A total of 1597 key administrators were called.

${ }^{b}$ From questionnaire responses. This represents about $10 \%$ of the 1905 principal investigators responding with filled-in questionnaires (positive response). 
Table 5. Sumary of mailing to, responses from, and referrals by principal investigators contacted in the National Biomonitoring Inventory. Numbers and percentages based on 6133 successful mailings

Number

Percent

Responders

$\begin{array}{ccc}\text { Positive }^{a} & 1905 & 31.1 \\ \text { Negative }^{b} & 1028 & 16.7 \\ \text { Total } & 2933 & 47.8\end{array}$

Nonresponders

3200

52.2

Referrals

New names

199

3.2

Previously ident ified names

407

6.6

Total

606

9.8

Volunteer responders ${ }^{a, c}$

629

10.3

$a_{A}$ total of 3031 project responses were received. Sone investigators forwarded questionnaires documenting more than one project. The average number of projects was 1.11 per investigator.

${ }^{b}$ Questionnaires returned with notation stating "no project" or "project not applicable."

${ }^{C}$ Questionnaire transmitled to nonaddressee by principal investigator contacted. 
nomination process. Using this ratio as an index of comprehensiveness of coverage, estimates of the number of principal investigators in a new "revised base" can be calculated. The number of investigators identified (6133) times the proportion of "new" to "old" names among referrals (0.5) equals the estimated number of projects not contacted (3066). Adding to the number of investigators identified (6133) this est imated number of investigators not contacted (3066) gives an estimated total number of investigators (9199).

Extra questionnaires were included in the package for transmittal to other investigators by the recipient of the questionnaire package. A total of 629 "volunteer" responses were received in this manner.

Several qualifications regarding these estimates should be noted. "Positive responses" included any responses for which a filled-in questionnaire was received. Neither the degree of completeness with which the questionnaires were filled in, nor applicability of the project under the definitions eslablished, werc taken into consideration. A significant number of positive responses had low informational content. Similarly, responses from investigators with nonapplicable projects were received despite the inclusion of a full-page definition of biological monitoring. Returns were classified into two categories only: biomonitoring and "other". All returns not qualifying under the definition of biomonitoring or otherwise failing to meet standards for usefulness of information (e.g. very incomplete returns) were included in the "other" class. Only qualified biomonitoring information was considered in subsequent reports.

Completeness of filling-in was adversely affecled by the longth of the questionnaire (four pages), as judged by comments from some participants. Receipt of nonapplicable projects was believed to be due partly to inattention or uncertainty by some responders and our difficulty in stating our operational definition, including limitations, of biological monitoring.

Procedures under consideration for improved comprehensiveness of coverage include:

1. Recontacting participating investigators by mail for referrals to new projects.

2. Identifying new Blologlcd liunitoring projects by reviewing current 11 teralure and then tolephoning potential participants.

3. Reviewing current file holdings on a state-to-state basis by persons with knowledge of biological monitoring activities within their area. Putential participants identified in this manner can be contacted initially by telephone and/or mail 
depending on numbers involved. In either case, detailed biological monitoring information can be solicited via our usual mail questionnaire.

4. Repeating the telephone interview procedure used initially but with emphas is on new projects.

Development and continuing maintenance of completely automated (computerized) files and data bases have greatly facilitated the cross-checking necessary to avoid duplication of effort which could result in irritating participants, consequent low participation, and significant waste of funds.

\section{SUMMARY}

The procedure employed to identify potential participant scientists for the National Inventory of SElected Biological Monitoring Programs was designed to achieve comprehensiveness of coverage and to enhance the quantity and quality of responses to mailed questionnaires. Telephoning key administrators to identify potential participants contributed significantly to this process. The mail questionnaire was the principal mechanism for developing information on biological monitoring throughout the U. S.

Considering the four-page length of the questionnaire and the complexity of information requested, the mail questionnaire procedure was more successful than expected (47.8\% participation, if both positive and negative responses are considered) with receipt of 3031 project descriptions. On the basis of new names from questionnaire referrals, an estimated two-thirds of the U. S. population of biomonitoring investigators received the mail questionnaire. We consider this degree of coverage to be quite good for initial development of a data base on biomonitoring projects. Telephoning key administrators provided a significant shortcut to the initially proposed scheme of telephoning principal investigators, contributed significantly to the degree of comprehensiveness achieved, and aided in developing a better product. 


\section{REFERENCES}

(Including directories used to identify key administrators)

American Medical Association. 1973. A Directory of Environmental Organizations in the United States. Chicago, Illinois. $7 \mathrm{pp}$.

Babbie, E. R. 1973. Survey Research Methods. Wadsworth Publishing Co., Blemond, California. pp. 131-169.

Champion, D. J., and Sear, A. M. 1969. Questionnaire Response Rate: A Methodological Analysis. Special Forces 47:335-339.

Clark, W. E, (ed.). 1974. Conservation Directory. National Wildlife Federation, Washington, D. C. 205 pp.

Council on Environmental Quality. 1973. The Federal Environmental Monitoring Directory. Washington, D. C. $105 \mathrm{pp}$.

Dillman, D. A., and Frey, J. H. 1974. Contribution of Personalization to Mail Questionnaire Response as an Element of a Previously Tested Method. Journal of Applied Psychology 59:297-301.

Eckland, B. K. 1965. Effects of Prodding to Increase Mail-back Returns. Journal of Applied Psychology 49:165-169.

Etzel, M. J., and Walker, B. J. 1974. Effects of Alternative Follow-up Procedures on Mail Survey Response Rates. Journal of Applied Psycho logy 59:219-221.

Food and Agriculture Organization of the United Nations. 1974. Directory of Institutions Engaged in Pollution Investigations. Rome, Italy. $43 \mathrm{pp}$.

Furniss, W. T. (ed.). 1973. American Universities and Colleges. American Council on Education, Washington, D. C. $1879 \mathrm{pp}$.

Gomez-Pompa, A., and Butanda, A. C. (eds.). 19/5. Index ur Current Tropical Ecology Research. Volume 1. Mexico, D. F. 227 pp.

Hochst im, J. R., and Atharianasopoulos, D. A. 1970. Personal Follow-up in a Ma1l Survey: Its Contribution and Its Cost. Public Opinion Quarter ly 34:69-81.

Hunsaker, D., and Dalgleish, R. 1970. Biological Field Stations of North America 1970. Organization of Inland Biological Field Stations. MSS Educational Publishing Company, Inc. New York. 
Jenkins, D. W. (ed.). 1972. Development of a Continuing Program to Provide Indicators and Indices of Wildlife and the Natural

Environment. Smithsonian Institution, Washington, D. C. $163 \mathrm{pp}$.

Jenkins, D. W. (ed.). 1974. The Role of Ecology in the Federal Government. Report of the Committee on Ecological Research. U.S. Government Printing Office, Washington, D. C. 78 pp.

Kawash, M. B., and Aleamoni, L. M. 1971. Effect of Personal Signature on the Initial Rate of Return of a Mailed Questionnaire. Journal of Applied Psychology 55:589-592.

Kemp, H. T. 1977. National Inventory of Selected Biological Monitoring Programs. Summary Report of Current or Recently Completed Projects, 1976. Oak Ridge National Laboratory Report ORNL/TM-5792, Oak Ridge, Tennessee. 649 pp.

Kemp. H. T., and Burgess, R. L. 1976. The National Biomonitoring Inventory: A Potential Aid to Planning Environmental Impact Statements. IN Proceedings of a Symposium on Biological Evaluation of Environmental Impact. 27th Annual AIBS Meeting, New Or learis. June 1976 (in press).

Matteson, M. T. 1974. Type of Transmittal Letter and Questionnaire Color as Two Variables Influencing Response Rates in a Mail Survey. Journal of Applied Psychology 59:535-536.

Miller, D. C. 1970. Handbook of Research Design and Social Measurement. David Mckay Co., Inc., New York.

Mitre Corporation. 1971. Monitoring the Environment of the Nation. Washington, D. C. $512 \mathrm{pp}$.

National Academy of Sciences, National Academy of Engineering, National Research Counci1. 1974. International Ecological Program Directory. Washington, D. C. 219 pp.

Nichols, R. C., and Meyer, M. A. 1966. Timing Post Card Follow-ups in Mail Questionnaire Surveys. Public Opinion Quarterly 30:306-307.

Paulson, G. (ed.). 1974. Environment U.S.A. A Guide to Agencies, People, and Resources. R. R. Bowker Co., Washington, D. C. 451 pp.

Potter, D. R., Sharpe, K. M., Hendee, J. C., and Clark, R. N. 1970. Questionnairies for Research. USUA Forest Service Research Paper PNW-140, USDA Forest Service, Port 1and, Oregon.

Robin, S. S. 1974. A Procedure for Securing Returns to Mail Questionnaires. Sociology and Social Research 50:24-35. 
Smithsonian Institution. 1970. National and International Environmental Monitoring Activities. Washington, D. C. 292 pp.

Smithsonian Institution. 1974. State Environmental Inventory Activities: A Guide to Individuals, Information Sources, and Selected Literature in Forty-Four States. Washington, D. C. 1028 pp.

Suffern, J. S., West, D. C., Kemp, H. T., and Burgess, R. L. 1976. Biological Monitoring and Selected Trends in Environmental Quality. ORNL/TM-5606. Oak Ridge National Laboratory, Oak Ridge, Tennessee. $30 \mathrm{pp}$.

Syracuse University Research Corporation. 1971. Environmental Research Laboratories in the Federal Government. New York. 973 pp.

The Institute of Ecology. 1974. Directory of Environmental Life Scientists. Volumes 1-9. Washington, D. C.

Thibeau, C. E. (ed.). 1972. Directory of Environmental Information Sources. 2nd Edition. The National Foundation for Environmental Contro 1, Inc., Boston, Massachusetts. $457 \mathrm{pp}$.

Tryzyna, T. C. (ed.). 1974. World Directory of Environmental Urganizations. Sierra Club, San Francisco, California. 155 pp.

U. S. Environmental Protection Agency. 1974. Directory of EPA, State, and Local Environmental Quality Monitoring and Assessment Activities. Washington, D. C. $384 \mathrm{pp}$.

Wilson, W. K. (ed.). 1974. Wor 1d Directory of Environmental Rèsearch Centers. 2nd Edition. R. R. Bowker Co., New York. 330 pp.

Wolff, G. R. (ed.). 1974. Environmental Information Sources Handbook. Garwood R. Wolff Co. 568 pp.

Young, R. A., Holl and, I. I., and Gilmore, A. R. 1970. Getting Better Returns from Mail Questionnaires. Journal of Forestry 68:723-724. 


\section{APPENDIX A}

Project documentation form, cover letter, and reminder letters used in conducting the National Inventory of Selected Biological Monitoring Programs.

A-1 through A-4 -- Project documentation form

A-5 -- Covering letter

A-6 -- First reminder letter sent two weeks after documentation form mailing

A-7 -- Second reminder letter sent five weeks after documentation form mailing 


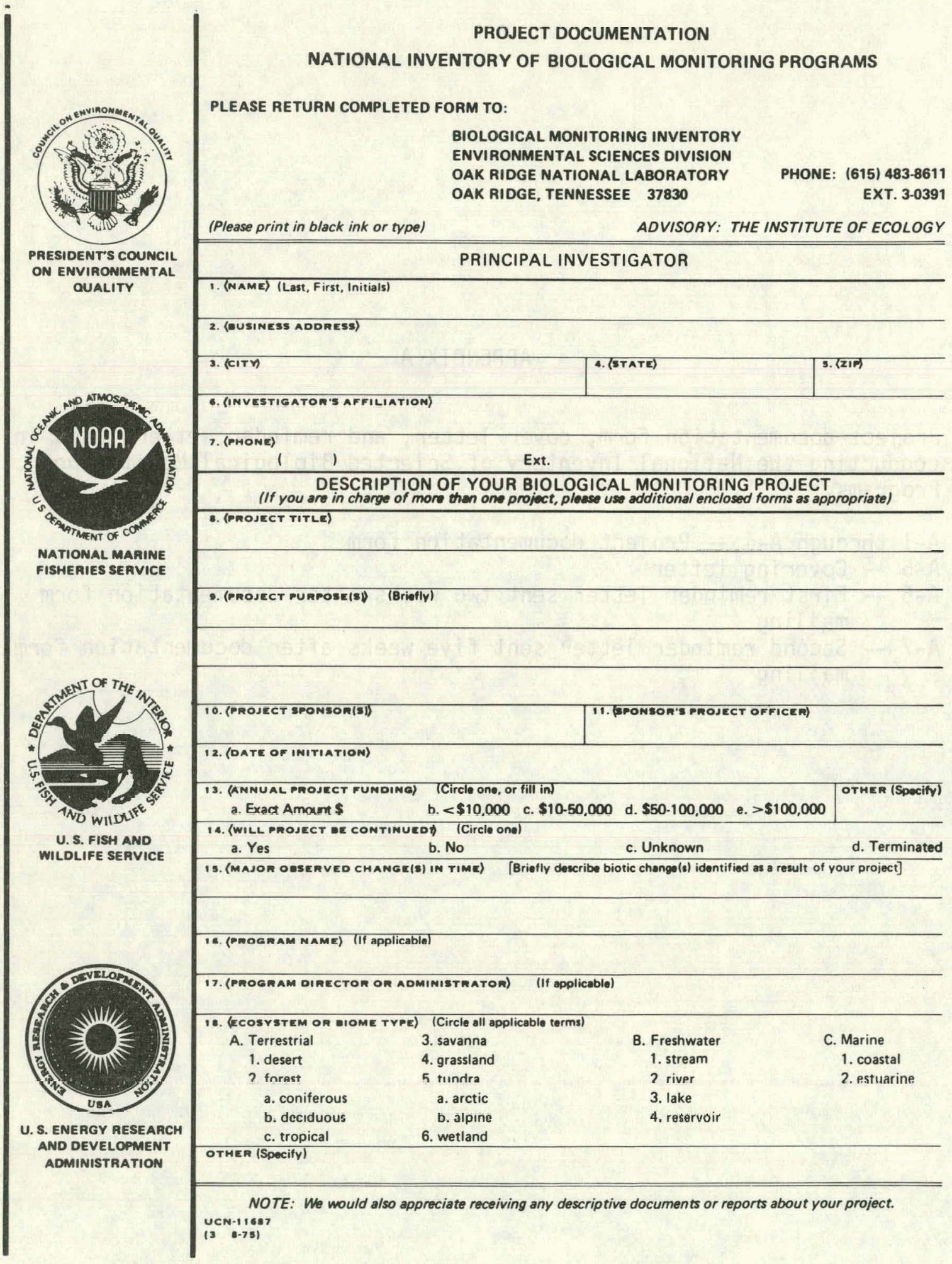




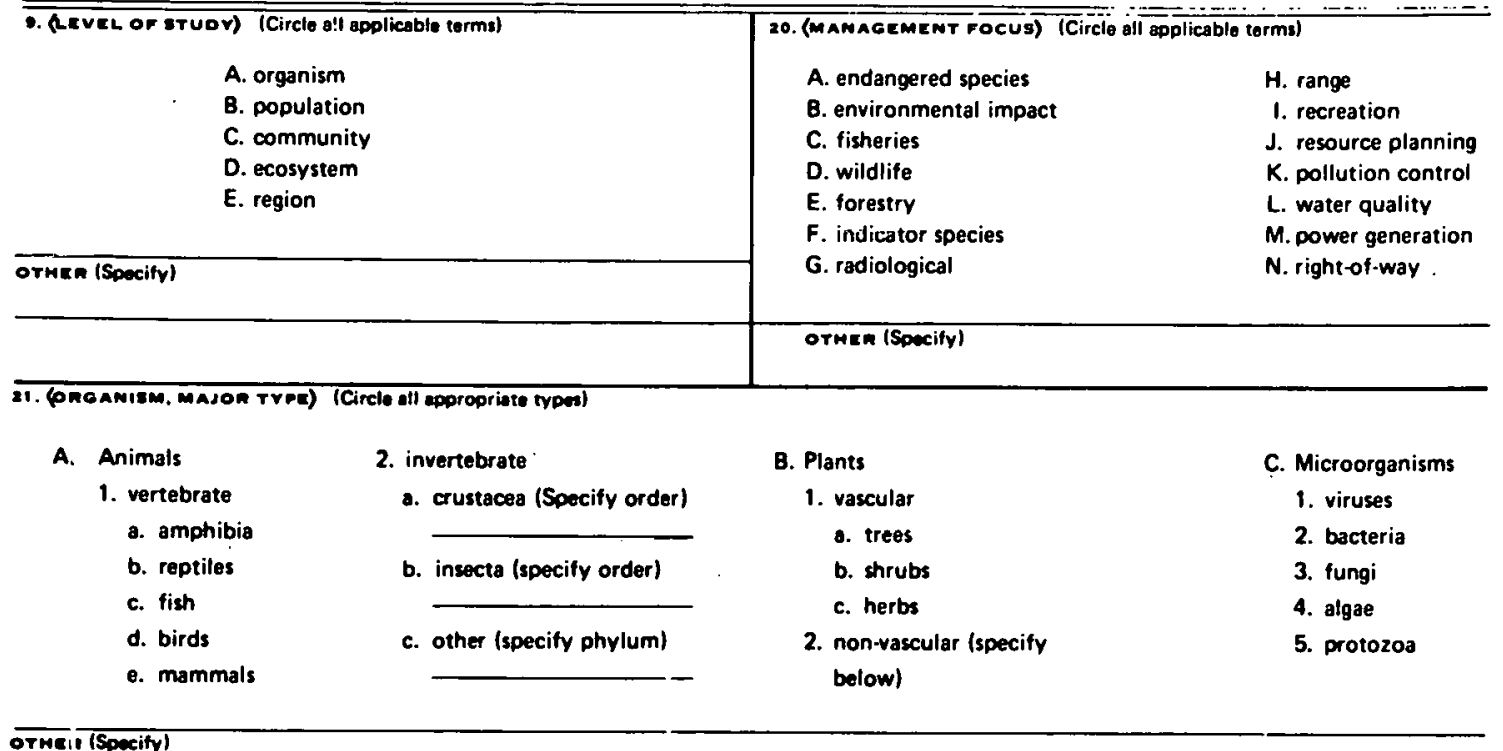

22. (TaxA) (Gomes and pocies, other toxonomic nemas, or common nemes if fow; or attech listing or publication, if numberous)

21. (kerwonos) (In eodition to thowe under other heed inges. Limit to 10 words)

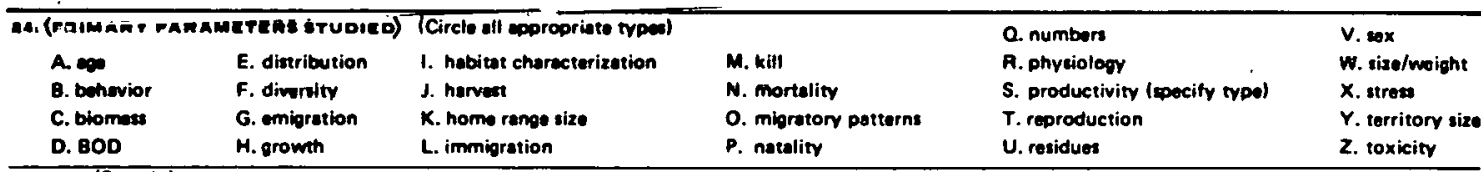

ormentspecily)

28. (suphontinc DATA COLLECTED) (Circle all mproprinte typen)

\begin{tabular}{|c|c|c|c|c|}
\hline $\begin{array}{l}\text { A. associated fauna } \\
\text { 8. askirialed flora }\end{array}$ & $\begin{array}{l}\text { C. associated microorganisms } \\
\text { U. atmospheric chemistry }\end{array}$ & $\begin{array}{l}\text { E. climatnlngisa! data } \\
\text { F. hydrological dato }\end{array}$ & $\begin{array}{l}\text { C. suils } \\
\text { H. terrain }\end{array}$ & 1. wàter quality data \\
\hline
\end{tabular}

U. atmospheric chemistry

F. hydrological dato

H. terrain

26. (WOW WERE PhIMARY OATA COLLECTEO1) (Ua stonderd terminology, if possiblo)

27. (EAMPLIMG FACOUEMCY)

\begin{tabular}{lllllllll} 
A. continuous & B. seasonal & C. daily & D. weekly & E. monthly & F. quarterly & G. annual & H. other periodic I. irregular \\
\hline
\end{tabular}




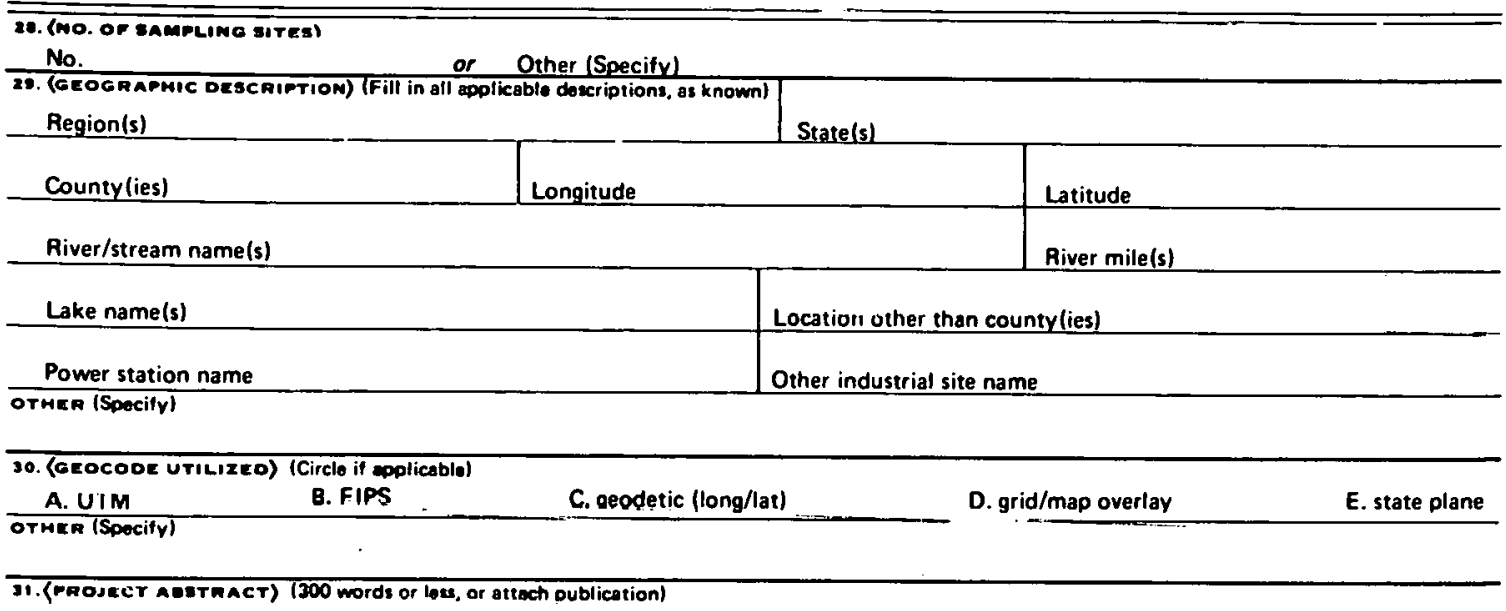

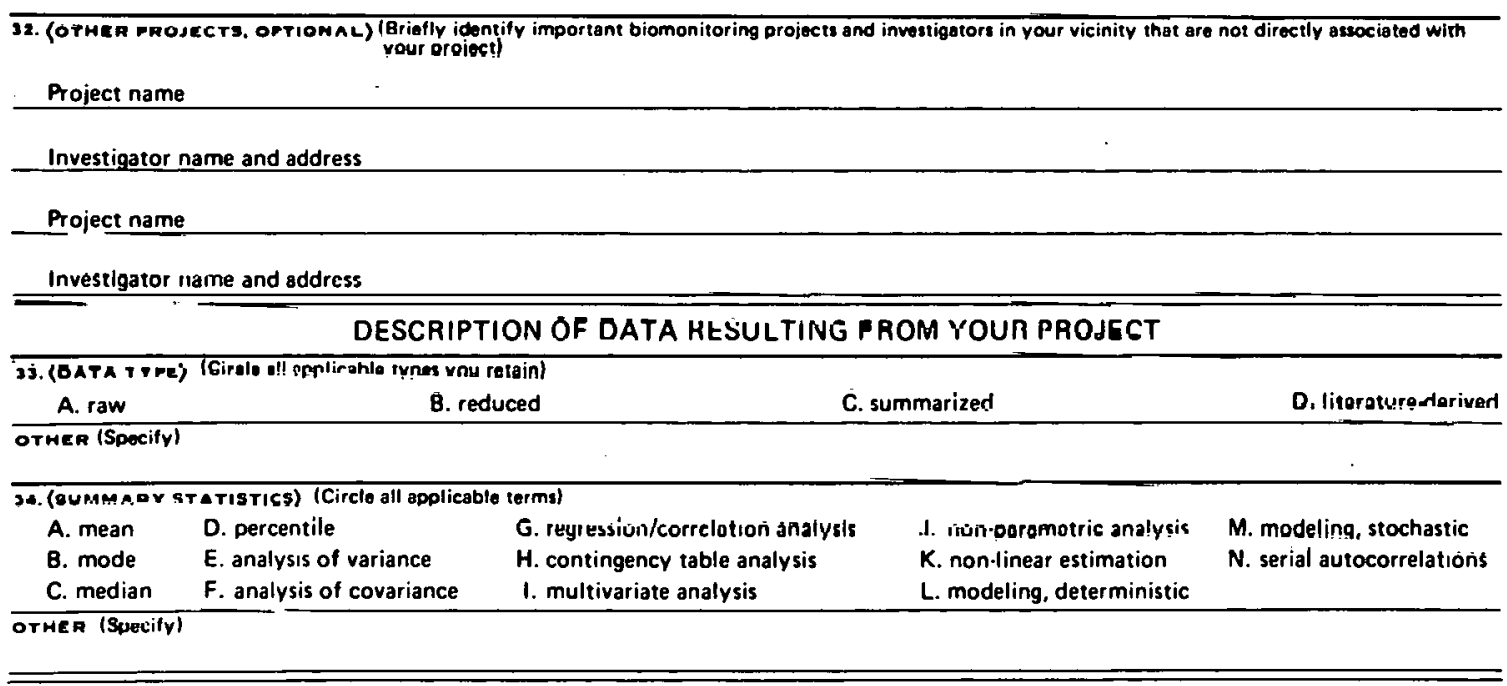




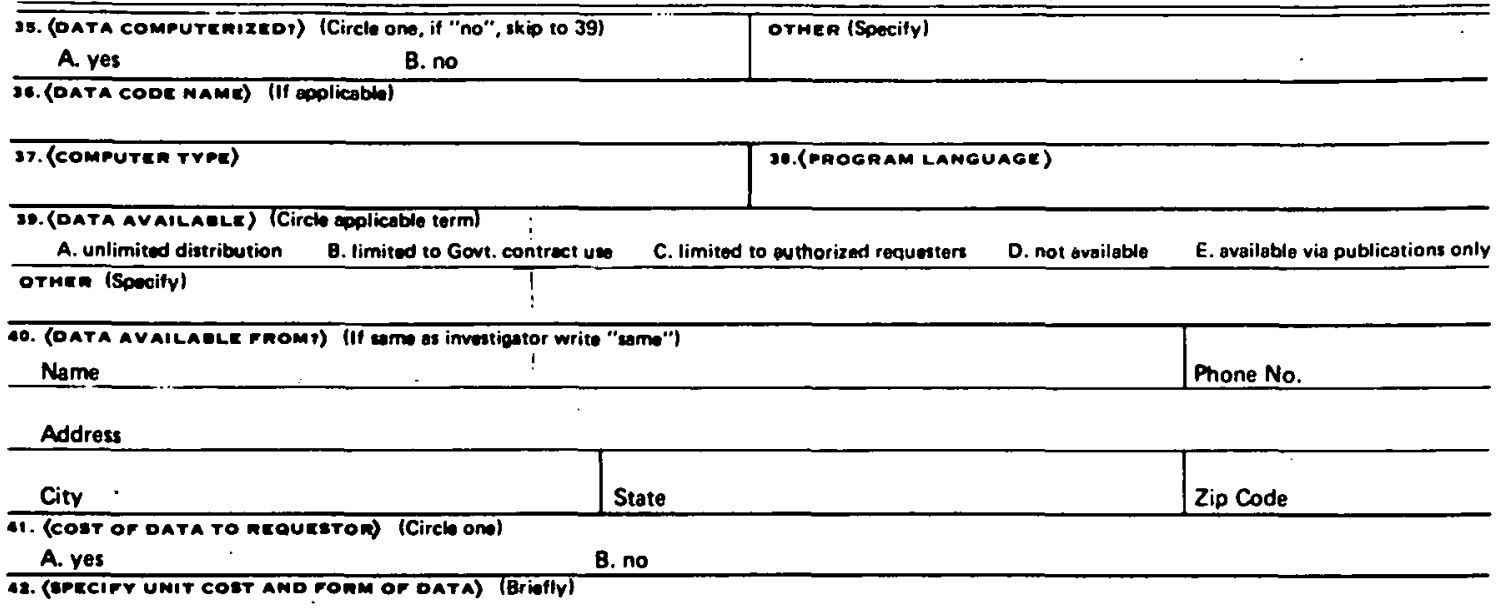

\section{as. (Fnerencince)}

Would you prefer a summary of biological monitoring programs in your State?

Region?

U.S.?

All three?

Or other? (Specify)

\begin{tabular}{|c|c|}
\hline & ADDITIONAL INFORMATION \\
\hline COMMENTS ON NEMANKS & \\
\hline
\end{tabular}

$1+$

NOTE: ANY COMMENTS, REMARKS, OR ADOITIONAL INFIRMATISN ARE WELCOMC.

PLEASE ATTACH AS DESIRED.

REMINDER: Wh would approciats neceiving any descriptive documents or reports about your projoct. 
EXECUTIVE OFFICE OF THE PRESIDENT

COUNCIL ON ENVIRONMENTAL QUALITY

722 JACKSON PLACE, N. W.

WASHINGTON, D. C. 20006

National Inventory of Selected Biological Monitoring Programs

Within the United States, an extensive amount of data has been collected on biological changes over time. In the aggregate, a formidable amount of information about our Nation's biota addresses such topics as wildlife, pests, exotics, rare and endangered species, various biotic communities, important natural areas, and other elements of ecosystems. These data and their sources, however, are extremely diverse and the capability is lacking for overviewing their scope and significance. Although a particular monitoring activity may be very useful for specific purposes, greater benefits may be realized if the resulting data are widely documented, dissemillated, and coordinater with other projects.

With your help, we intend to produce a comprehensive inventory of U.S. biological monitoring activities as a foundation for such an overview. Through pertinent directories, key administrators, and knowledgeable advisors, your work has been identified as potentially appropriate for inclusion in our inventory. The package you have received today includes a cover letter, biomonitoring definition sheet, inventory form, and self-addressed, prepaid (franked) envelope. We intend to produce a computerized data base that would be easily accessible to interested individuals. This base is to be informative in nature, not evaluative, and will provide for more unified decision-making concerning our nation's living natural resources. The data base will be searched on request and made available to selected users via an existing on-line dial-up computer capability. A printed summary will be prepared and copies provided free-of-charge to participants.

When completed, such a data base will be valuable in environmental analyses and evaluation programs at all levels of private enterprise and government, for regional and global assessments of environmental insults, and for regulative purposes. The data base will be maintained on a continuing basis.

Enclosed are three sets of documentation forms in the event that you are a principal investigator for more than one project. Or, if you have a colleague involved in biomonitoring activities, please pass any extra forms on to him. If you determine that you cannot comply or that your project does not fit our biomonitoring definition, please return the forms with an appropriate notation.

You have in your hands the critical medium for a nationwide inventory of biological monitoring studies. Its authenticity and potential benefits depend on your most capable cooperation. There will probably never be a better time to complete the inventory form than now. Please slip it into the prepaid envelope and drop it in the mail.

Your participation will be greatly appreclated.

Sincerely,

James J. Reisa, Project officer

JJR:al

Enclosures 
EXECUTIVE OFFICE OF THE PRESIDENT

COUNCIL ON ENVIRONMENTAL QUALITY

122 JACKSON PLACE, N. W.

WASHINGTON, D. C. 20006

"National Inventory of Biological Monitoring Programs"

A couple of days ago we sent you an inventory form along with a prepaid, self-addressed envelope for your convenience in returning your input for our nationwide inventory of biological monitoring projects. The mail, we realize, sometimes moves with less than alacrity. So, if you have already returned your project documentation, please consider this letter a special "thanks" for your promptness.

If, as we sometimes do ourselves, you've allowed the forms to slip to an overburdened area of your desk, please take this opportunity to unburden the inventory form, complete it now, and drop it in the mail. There will probably never be a better opportunity than that presently at hand.

Thanks again for your assistance.

Sincerely,

James J. Reisa, Project Officer

JJR:al 
EXECUTIVE OFFICE OF THE PRESIDENT

COUNCIL ON ENVIRONMENTAL QUALITY

122 JACKSON PLACE, N. W.

WASHINGTON, D. C. 20006

\section{NATIONAL INVENTORY OF BIOLOGICAL MONITORING PROGRAMS}

We are in the final stages of preparing project documentations fur data analysis and are still anticipating arrival of your completed inventory form. We trust that you have received at least one of the forms along with a self-addressed, prepaid, stamped envelope for your convenient participation in this project.

If you have previously mailed your completed form, please consider this a well-deserved thanks for your efforts in our mutual behalf. Should you have further questions, please do not hesitate to write or call for clarification or assistance. (Telephone 615-483-8611, ext. 3-0391 or FTS 850-0391).

An additional copy of the documentation form is enclosed for your convenience.

To date documentation of more than 2400 projects has been received. Each state is represented with some exceeding 150 documented projects. The maximum value of our effort can be achieved only by documenting as many as possible of the biological monitoring projects in every state. Again, we believe this data base w1ll be invaluable to you in your work and to your colleagues in private and public institutions.

Your cooperation in this matter will be greatly appreciated.

sincerely,

James J. Reisa, Project Officer

JJR:al

Enclosure

Note: Please return the blank form with an appropriate notation if you determine that your project is not applicable or that you are unable to participate. 
INTERNAL DISTRIBUTION

$\begin{aligned} \text { 1-28. } & \text { S. I. Auerbach } \\ 29 . & \text { R. W. Brocksen } \\ \text { 30-32. } & \text { R. L. Burgess } \\ \text { 33-35. } & \text { F. G. Goff } \\ 36 . & \text { W. F. Harris } \\ 37 . & \text { E. E. Huber } \\ 38 . & \text { S. V. Kaye } \\ \text { 39-48. } & \text { H. T. Kemp } \\ 49 . & \text { R. L. Kroodsma } \\ 50 . & \text { H. F. McDuffie } \\ 51 . & \text { J. S. Olson } \\ 52 . & \text { R. J. Olson } \\ 53 . & \text { D. C. Parzyck } \\ \text { 54-55. } & \text { H. Pfuderer } \\ 56 . & \text { H. Postma }\end{aligned}$

57. D. E. Reichle

58. C. R. Richmond

59. E. G. Struxness

60. J. S. Suffern

61. T. Tamura

62. G. U. Ulrikson

63. R. I. Van Hook

64. J. A. Watts

65. D. C. West

66. Biology Library

67-68. Central Research Library

69-70. Laboratory Records Dept.

71. Laboratory Records, ORNL-RC

72.. ORNL Y-12 Technical Library

73. ORNL Patent Office

\section{EXTERN/L DISTRIBUTION}

74. Research and Technical Support Division, DOE-ORO

75. T. Albert, Office of Environmental Information Systems, DOE, Washington, DC 20545

76. T. Armantano, TIE, Holcomb Research Institute, Butler University, Indianapolis, IN 46208

77. F. P. Baxter, Division of Forestry, Fisheries, and Wildlife Development, Tennessee Valley Authority, Norris, TN 37828

78. J. D. Buffington, Couricil on Environmental Quality, 722 Jackson Plare, NW, Washington, DC 20006

79. J. F. Callahan, Ecosystem Studies Program, NSF, Washington, DC 20550

80. Tom Gilbert, National Park Service, Department of the Interior, Washington, DC 20240

81. A. Hirsh, Office of Biological Services, Fish and Wildlife Department of Interior, $1730 \mathrm{k}$ St., NW, Washington, DC 20240

82. C. M. Larsen, Fisheries Research Management Division, Department of Commerce, NOAA, National Marine Fisheries Service, Washington, DC 20235

83. J. L. Liverman, Assistant Secretary for Environment, DOE, Washington, OC 20545

84. 0. Loucks, Department of Botanny, Universily of Wisconsin, Madison, WI 53/06

85. R. P. McIntosh, Ecology Program, National science foundation, Washingtori, oC 20550

86. C. E. Miller, Office of Environmental Information Systems, DOE, Washington, DC 20545

87. W. C. Osburn, Office of Biomedical and Environmental Research OBER, DOE, Washington, DC 20545 
88. J. J. Reisa, Council on Environmental Quality, 722 Jackson Place, NW, Washington, DC 20006

89. P. Risser, Department of Botany and Microbiology, University of Ok lahoma, Norman, OK 73069

90-94. J. W. Ross, Education Department, Callaway Gardens, Pine Mountain, Georgia 31822

95. Ed Schofield, TIE, Holcomb Research Institute, Butler University, Indianapolis, IN 46208

96. J. A. Sherk, Office of Biological Services, Department of Interior, $1730 \mathrm{~K} \mathrm{St}$., NW, Washington, DC 20240

97. W. T. Swank, Director, Ecosystem Studies Program, National Science Foundation, Washington, DC 20550

98. J. Swinebroad, Office of Biomedical and Environmental Research DOE, Washington, DC 20545

99. L. Trott, National Marine Fisheries Service, NOAA, Department of Commerce, Washington, DC 20235

100. J. H. Wilson, Office of Environmental Information Systems, DOE, Washington, DC 20545

101-127. Technical Information Center, Oak Ridge, TN 37830 